TEME, г. XLIV, бр. 2, април - јун 2020, стр. 423-438

Прегледни рад

https://doi.org/10.22190/TEME191015004B

Примљено: 15. 10. 2019.

Ревидирана верзија: 13. 12. 2019.

Одобрено за штампу: 15. 4. 2020.

\title{
THE CAUSES AND PREVENTION OF INJURIES IN HANDBALL
}

\author{
Ivana Bojić ${ }^{1}$, Zoran Valdevit ${ }^{2}$, Marina Veličković ${ }^{1}$ \\ ${ }^{1}$ University of Niš, Faculty of Sport and Physical Education, Niš, Serbia \\ ${ }^{2}$ University of Belgrade, Faculty of Sport and Physical Education, Belgrade, \\ Serbia \\ *bojicka2003@yahoo.com
}

\begin{abstract}
The aim of this work is to present and analyse the handball literature on the causes of injuries, types of injuries and their anatomic locations, as well as the prevention measurements. Based on the results of the analyzed studies, it can be concluded that there is a significant number of injuries, of different body parts and of different severity in top-level handball players. Overuse injuries (to certain body parts, such as the more dominant shoulder, the ankle and the knee) are considered to be the most prominent. In order to prevent the injuries to the mouth and teeth, the use of mouthguard is recommended. When it comes to the prevention and rehabilitation of shoulder injuries, the research results have shown positive effects that the training aiming at the increase of the inner rotation of the glenohumeral strength, the outer rotation strength and the scapular muscles strength has along with the exercises for improving the kinetic chain and the chest flexibility. The use of elastic bands and the medicine ball has proven efficient in increasing the shoulder area strength, and the whole swing and throw movement. The ankle and the knee are the most frequently injured joints among female handball players. The results of the application of the neuromuscular training, the proprioception and the balance exercises, combined with some specific players' activities (running, jumping and planting) show that such training process is efficient in the prevention of injuries to ankle and knee joints.
\end{abstract}

Key words: handball, injuries, etiology, prevention.

\section{УЗРОЦИ И ПРЕВЕНЦИЈА ПОВРЕДА У РУКОМЕТУ}

\section{Апстракт}

Циљ рада наративно-прегледног карактера био је да се прегледом рукометне литературе анализирају узроци повреда, њихове врсте и анатомска позиција, као и мере превенције повређивања играча. На основу резултата анализираних истраживања, постоји велики број повреда, различите локације и степена тежине којима су изложени спортисти у врхунском рукомету. Повреде узроковане прекомерном употребом појединих делова тела (доминантно раме, скочни зглоб и колено) сматрају се 
најбројнијим. У циљу превенције повреде устију и зуба, препоручује се употреба гуменог штитника. У превенцији и рехабилитацији повреда рамена, резултати су показали позитивне ефекте тренинга за повећање унутрашње ротације гленохумералне снаге, снаге спољне ротације и јачине скапуларних мишића, као и за побољшање кинетичког ланца и покретљивости грудног коша. Употреба еластичних трака и отежавајућих лопти „медицинки” показала се ефикасним у повећању снаге раменог поја$\mathrm{ca}$, као и јачању целокупног покрета замаха - избачаја лопте. Скочни зглоб и колено су међу најчешће повређиваним зглобовима рукометаша. Резултати примене неуромишићног тренинга, проприоцепције и вежби равнотеже, у комбинацији са специфичним активностима играча (трчање, скокови и приземљења) - показали су се ефикасним у превенцији повређивања скочног зглоба и колена.

Кључне речи: рукомет, повреде, етиологија, превенција.

\section{INTRODUCTION}

Handball is an attractive and dynamic sports game with a ball. The movements predominant in handball are sprints with sudden changes in direction, numerous jumps, various throws and shots, the contact between the players as well as specific goalkeepers' activities. The direct contact with the opponent is allowed but strictly regulated by the official rules of the game. The purpose of such duel is to interfere with and slow down the activities of the offense preventing the opponent to come close to and, in that way, threaten the goal, as is to use the tactic for frequent breaks. The role of the referees is to maintain fair play and to penalise prohibited and harsh fouls. Periodical updates to the official rules and regulations just prove the point of handball being constantly developed and improved, which can be seen in the constant enhancement of speed, strength, technical and tactical abilities of the players. The latest changes introduced in 2016, among other things, particularly emphasize the introduction of stricter rules in order to prevent unsportsmanlike behaviour that leads to injuries (the introduction of the blue penalty card after the red one has been shown), and to increase the attractiveness and the quality of the game. However, aggressive contacts represent the inevitable part of this sport and the most probable cause of the players' injuries. Some earlier research showed that of all the recorded injuries between $40 \%$ and $84 \%$ had been induced by the direct contact between the players (Fagerli, Lereim, \& Sahlin, 1990; Nielsen \& Yde, 1988). Top-level players involved not only in club competitions, but also in the activities of their national teams, participate in 70 to 100 games per season on average. Depending on the competition level and the number of the players in the team, the extent to which the players are exposed to physical pressure is different but high nonetheless, due to the fact that the breaks during important competitions are short, the example of which was the European Championship when top teams had to play 8 games in 13 days (Laver \& Myklebust, 2015). The high levels of frequency and load during such games undoubtedly cause fatigue and overload so if there is no balance between playing and recuperating during the training and 
competition periods, different types of injury may occur (Andersson, Bahr, Clarsen, \& Myklebust, 2018). Unfortunately, although there is a tendency for the players to try to avoid being injured, this is a very common and unavoidable phenomenon peculiar to handball (Laver \& Myklebust, 2015; Bere et al., 2015). Preventing injury in handball is a burning issue among players, coaches and other experts who try to adjust the training process to reduce or prevent the most common causes of injury (Nasiri, 1994; Langevoort, Myklebust, Dvorak, \& Junge, 2007). The statistics show that the number of injuries among young players is on the increase, which makes prevention the most important task to accomplish. In younger players, aged 15 to 18 in particular, there is a difference between muscle strength and coordination. For this reason, Reckling, Zantop, \& Petersen (2003) recommend proprioception training as well as the exercises for improving jumping techniques and the specific finger muscle strength increasing training, all of them with the purpose of preventing injuries. Another thing that could influence the reduction of the number of contactinduced injuries might be emphasizing fair play between young players.

The aim of this work is to analyse handball literature for the causes of injuries, their types and anatomic locations, including the ways of preventing injuries in the first place.

\section{THEORETICAL CONSIDERATIONS OF THE PROBLEM}

Etiology (the causes and consequences) of injuries in handball has been the focal point of many authors' research in the past decades (Rasuli, Jafari, Barghi Moghaddam, \& Narenjichi Shotorbani, 2012; Zebis et al., 2011; Langevoort et al., 2007; Reckling et al., 2003). Determining the frequency of injury among female handball players during the games or training sessions, the authors noted a larger number of more complex injuries during the games, and those were the injuries to the lower extremities $(63.44 \%)$, the body $(13.01 \%)$, whereas during the training sessions the injuries were more common to the upper extremities (42.52\%), the head and the neck (4.62\%). Injuries to the muscles were more common than the injuries to the bones, both in training sessions and in the games (Rasuli et al., 2012).

The more actively involved, certain extremities and body parts are in completing technical tasks in the game (the shooting shoulder, the leg used for jumping, the lower part of the back), the higher is the probability of injury to wrists and ankles, ligaments and the muscle-tendon connection as the consequence of overuse injuries. Clarsen, Myklebust, \& Bahr (2012) applied new methods in their three-month-long study - a questionnaire for registering afore mentioned injuries which was filled in on a weekly basis (the total 313 sportspeople involved in five different sports (handball included) filled in the questionnaire). The questionnaire included the 
injuries to the shoulders, lower back and the knees and the time-loss injuries. It showed 419 overuse problems of those body parts, a third of which was classified as significant, leading to moderate or serious decrease in achievement or participation, or even a complete break in training. It should also be mentioned that it often happens that players continue with their training sessions or competitions enduring pain in the mentioned body parts, which is also another injury-causing or an injury-prolonging factor that demands a longer period of time off the floor (Jost, Zumstein, Pfirrmann, Zanetti, \& Gerber, 2005). The contact game between the players very often results in mouth and teeth injuries so it is recommended that the mouthguard should be used, which reduces the frequency of such injuries up to 5.5\% (Petrović, Kühl, Šlaj, Connert, \& Filippi, 2016). However, only a small number of players who are most commonly involved in rough contacts with the opponents uses the mouthguard (28\%) (pivots and the offense players, as well as the ones who have already suffered from a difficult injury) (Bergman et al., 2017). Some research undertaken in the late 90s showed that out of the total number of the acute injuries among handball players the most common were the ones of the ankle, the knees and the more dominant shoulder, whereas among goalkeepers the most common were the injuries to the hips (Seil, Rupp, Tempelhof, \& Kohn, 1997). The authors suggested that the most of them were inflicted during the defensive activities of the players (cc 2/3) and the rest (1/3) during the counter-attacks. Generally speaking, body contact, landing and running represent the most common causes of injury in handball. Unfortunately, the rise in dynamic and speed in modern handball has brought about the negative change in the type and frequency of injury. The questionnaires filled in by the coaches and physiotherapists of Icelandic elite handball teams showed that the most frequent injuries among the players were the ones to the knees (26\%), the ankles $(19 \%)$ and the feet/toes (17\%), and that overuse injuries appeared in the lower back/the pelvis (39\%), the dominant shoulder (21\%) and the knees (21\%). It is noted that the previous injuries were the main cause of the new ones (Rafnsson, Valdimarsson, Sveinsson, \& Arnason, 2019). Popović \& Lemaire (2002) conducted their own study of the elbow injuries among 30 top handball goalkeepers. The particularity of their training programme and the preparation activities of the joints for blocking the shots result in a very specific load onto the elbows and wrists, including all the surrounding structures. The goalkeeper's elbow has a specific nature due to the biomechanics of sudden arm movements and repeated fast elbow movements and forceful contacts during the defensive activities, which caused visible injuries to the collateral elbow ligament in $50 \%$ of the examinees. It is the fact that these particular joints of handball goalkeepers are highly traumatised, which was proven by constant inflammations of tendon and synovial membrane of the elbow in $66 \%$ of the examinees. It is worth mentioning that most of the injuries were inflicted during the game and not 
in the training sessions. Generally speaking, the most common cause of acute injuries is the demanding game itself with the joints and shoulders being overburdened. When it comes to the overload syndrome, the causes can be found in the frequency of certain movements repetition and the strain on all the joints (Vlak \& Pivalica, 2004).

\section{INJURIES TO THE SHOULDERS AND THE PREVENTION}

According to certain statistical data from the 90s, during one competition season top-level players performed around 48000 throws using the more dominant arm, which meant that a player made 20 circular arm movements per minute with the maximum ball speed of 150 to $170 \mathrm{~km} / \mathrm{h}$ (Fiesler et al., 2015; Gohlke, Lippert, \& Keck, 1993). Taking into account the fact that the game has significantly transformed in the past two decades when it comes to the speed of tempo, it is obvious that the number of throws per annum has also increased. In addition, handball players use different types of throws, with the upper arm above and below the shoulder line thus exposing the shoulders to the contacts and blocks while the arm is in the uplifted position. The forces that occur on the anatomic structures of the dominant shoulder during the throw can exceed the body weight of the player by 1.5 times (Lubiatowski et al., 2017; Clarsen, Bahr, Andersson, Munk, \& Myklebust, 2014; Myklebust, Hasslan, Bahr, \& Steffen, 2011; Gohlke et al., 1993). Therefore, injuries to the shoulders are quite common in handball players and they appear as the result of the repeated throwing movements and incessant forces applied to the shoulders. Laver, Landreau, Seil, \& Popović (2018) maintain that the handball shoulder represents a typical model of the injury that occurs due to the overuse, that is, due to a large number of repeated throwing movements using the more dominant $\mathrm{arm}$. The repetition connected with fast throws can change the status of the stability-mobility, which is the main factor of shoulder injuries. Repetitive movements related to throwing can induce multiple changes to the bones and soft tissue, which can further lead to the intensified outer rotation and limited inner one (Meister, Buckley, \& Batts, 2004). Injuries to the shoulder make up 4 to $27 \%$ of all the injuries inflicted in handball (Giroto, Hespanhol Junior, Gomes, \& Lopes, 2017; Langevoort et al., 2017; Bere et al., 2015). The reason for such disparity can probably be ascribed to the fact that certain publications have included only acute injuries, whereas some others also included overuse injuries as well. The adequate dosage of the work load and the right estimate of the shoulder condition deterioration can significantly contribute to the prevention and reduction of more serious shoulder injuries. Contemporary prevention which combines specific programmes for the correction of the scapular muscle imbalance including stretching and shoulder strengthening has proven to give promising results (Laver et al., 2018; Østerås, Sommervol, \& Skjølberg, 2014). In cases of 
the dominant shoulder weakness, it is recommended to work on increasing outer rotation. Some of the training methods proven efficient when it comes to the specific shoulder strength in female handball players include the use of elastic bands during the warming-up phase of the training process, followed by handball-specific throws and the throws with the medicine ball (Mascarin et al., 2017; Raeder, Fernandez-Fernandez, \& Ferrauti, 2015). In cases of deteriorating changes in the shoulder, the training process should be focused on stretching the back capsule of the shoulder, strengthening the rotator cuff group of muscles from the back of the shoulder (m. supraspinatus, $\mathrm{m}$. infraspinatus, $\mathrm{m}$. teres minor) and the revitalization of the flexibility and muscular balance of the scapular muscles (Cools, Johansson, Borms, \& Maenhout, 2015). The programme of the prevention of the shoulder injuries in male and female handball players (Andersson, Bahr, Clarsen, \& Myklebust, 2016; Clarsen et al., 2014) encompassed the exercises for the enhancement of the outer and inner rotation volume, the strength of the scapular muscles and the improvement of the kinetic chain and the chest flexibility. The results showed the reduced risk of shoulder injuries and suggested that those exercises should be included in the warming-up part of the training process in handball. However, some authors did not find any positive influence of such exercises on the strengthening of the shoulder area to prevent the pain in young female handball players (Sommervold \& Østerås, 2017).

\section{INJURIES TO THE ANKLES AND THE PREVENTION}

Many studies have proven that the ankle and the knee are the body parts most susceptible to injury in handball (Seil et al., 1997). Statistical data show that injuries to the ankle and the knee make up 19\% to $44 \%$ of the total number, with the younger players and the ones who have already suffered the same particularly prone to them (Laver, et al., 2018; Laver \& Myklebust, 2015; Bere et al., 2015; Clarsen, Myklebust, \& Bahr, 2012; Rasuli et al., 2012). The most common causes of those injuries, according to the authors, are overuse and landing on the opponent player's foot. This is the reason why both contemporary training practice and theory seek to discover new, more efficient exercises and methods to prevent all types of injury in handball. One of the more traditional methods, the balance training, is used as a part of a rehabilitative programme for ankle injuries. Nowadays, the balance training (proprioception) is used to prevent sports injuries (Eils, Schröter, Schröder, Gerss, \& Rosenbaum, 2010; Söderman, Werner, Pietilä, Engström, \& Alfredson, 2000). Research has proven that poor ability to achieve balance is closely linked to the increased risk of ankle injuries in various activities (Hrysomallis, 2007). However, it is also emphasized that the combination of balance training and the exercises involving jumps, landing and agility resulted in a significant decrease in 
ankle and knee injuries in handball players (Mascarin et al., 2017). The combination of the functional strength training and neuromuscular training, with the usage of proprioception exercises on various balancers ("ankle disk", balance cushion, Bosssa \& fitnessball, "wobble board"), significantly reduces the number of moderate and complex injuries to the ankle in female handball players Wedderkopp, Kaltoft, Holm, \& Froberg, 2003). Some authors have also proven the importance of the relation of strength between antagonistic muscle groups while making certain movements as a way of preventing injuries (Ødegaard \& Risberg, 2005). There are other more common procedures, such as stretching and warming-up exercises, which are done before the training sessions and games for the players to be fully prepared. Those procedures are also very useful in preventing injuries. In addition, isokinetic machines can also be used for the purpose of prevention and rehabilitation.

\section{INJURIES TO THE ANTERIOR CRUCIATE LIGAMENT AND THE PREVENTION}

In sports, such as handball, fatigue is closely related to the higher risk of injuries to the anterior cruciate ligament (ACL). The influence of fatigue on the muscular function can be evaluated in both static (isometric) and dynamic conditions. The effect of muscular fatigue caused by neuromuscular activity stimulated by a handball game, swift sidecutting movements, can be linked to the frequency of the ACL injury (Zebis et al., 2011). Zebis et al. (2011) used electromyography to test neuromuscular activity of female handball players on the force platform, before and after a simulated handball game. The players did swift sidecutting movements on the platform and the EMG results showed the reduction of strength in the observed muscles of the quadriceps and harmstring, as well as the selective decrease in the muscular activity of the harmstring during swift sidecutting movements. These authors also recommend that screening procedures should be included in functional movements to expose specific deficits caused by the fatigue in the activation of $\mathrm{m}$. quadriceps the most important extensor in the knee joint during highrisk phases of the game. ACL injuries are considered particularly complex in every sport, handball included. After such injury, recuperation and recovery are not quick. On the contrary, it takes a few months for a player to be fully prepared for the competition level. Even though the etiology of ACL injuries is not quite clear, it is considered that the causes involve the combination of multiple factors: neuromuscular, biomechanic, anatomic, hormonal and genetic (Svoboda et al., 2016; Shultz et al., 2012). When it comes to women, ACL injuries appear in the sports which require agility, and which are dominated by swift direction changes, one-leg landings, all those situations in which a player is out of balance and almost always without any direct contact with the knee, the sports such as handball and football. Studies have shown 
that the number of ACL injuries is 2 to 8 times higher in female players than in male (Michaelidis \& Koumantakis, 2014; Agel, Arendt, \& Bershadsky, 2005; Arendt \& Dick, 1995; Bjordal, Arnly, Hannestad, \& Strandt, 1997). The possible reasons for women being exposed to a higher risk of suffering from ACL injuries might be specifically anatomic, hormonal, gender related and neuromuscular (NM) factors (Michaelidis \& Koumantakis, 2014; Alentorn-Geli et al., 2009; Hootman, Dick, \& Agel, 2007; Griffin et al., 2006; Hewett, Myer, \& Ford, 2006). Apart from the injuries that occur as the consequence of the direct contact between the players, there are injuries of mechanical nature (contact with the goal frame, the fence, etc.) and noncontact injuries (Paszkewicz, Webb, Waters, Welch McCarty, \& Van Lunen, 2012; Renstrom et al., 2008). Non-contact ACL injuries usually happen as the consequence of the sudden changes in direction and movements and pivoting (Michaelidis \& Koumantakis, 2014; Krosshaug et al., 2007; McLean, Huang, \& Van Den Bogert, 2005; McLean et al., 2005b; McLean, Huang, Su, \& Van Den Bogert, 2004; Olsen, Myklebust, Engebretsen, \& Bahr, 2004; Arendt \& Dick, 1995), as well as in one-leg landings of a player (Michaelidis \& Koumantakis, 2014; Krosshaug et al., 2007; Olsen et al., 2004; Arendt \& Dick, 1995). Therefore, it is believed that the importance of balance in neuromuscular control is important, and that the balance training (the proprioreceptive training with various balancers) helps preventing injuries to the lower extremities (Achenbach et al., 2018; Steffen et al., 2012; Waldén, Atroshi, Magnusson, Wagne, \& Hägglund, 2012; Mandelbaum et al., 2005; Olsen, Myklebust, Engebretsen, Holme, \& Bahr, 2005). However, in order to prevent ACL injuries, experts believe that it is crucial to continue conducting research into the effects that preventive training programmes have, as is the importance of determining the causes of injuries (gender and age, technique, previous injuries, experience in sports) (Setuain, Millor, Alfaro, Gorostiaga, \& Izquierdo, 2015; Shultz et al., 2012). Conducting the neuromuscular and proprioceptive training on different balancers with the purpose of preventing knee injuries has proven efficient by a number of studies (Achenbach et al., 2018; Herman, Barton, Malliaras, \& Morrissey, 2012; Wedderkopp, Kaltoft, Lundgaard, Rosendahl, \& Froberg, 1999; Myklebust et al., 2003; Thacker et al., 2003; Petersen et al., 2005; Petersen et al., 2002). More frequent proprioceptive training sessions with adolescents have significantly reduced the number of serious knee injuries, ACL included. Myklebust et al. (2003) also had a significant decrease in the number of ACL injuries by applying the prevention programme but with the elite handball players only. On the other hand, the study conducted by Petersen et al. (2005) under the same protocol was not successful in preventing ACL injuries. Both protocols were comprised of balance exercises, plyometric exercises and the education about the adequate techniques of conducting a multi-component programme. In the second year of the preventive programme application, which lasted throughout the season, 
Myklebust et al. (2003) added some specific handball agility exercises with the focus on the correct running and planting techniques. The results were thus even more impressive. The positive outcome of these protocols was probably influenced by the length of its application. Some authors claim that it takes a minimum of six weeks of the preventive programmes application for them to be successful (Hewett et al., 2006), as well as a minimum of once a week application throughout the season (Michaelidis \& Koumantakis, 2014). Examining knee injury prevention measurements, some authors concluded prolonging the buffering when landing, which involves squatting after planting, there would be a higher circular momentum in the knee joint, a smaller effect of the force of the contact with the surface and a higher circular momentum in the ankle during the plantar flexion. It practically means that with the decrease of the knee bending angle during the phase of planting, a protective mechanism is created which shields ACL from a powerful strain and injury (Ameer \& Muaidi, 2017). One of the training methods that helps knee injury reduction and prevention according to certain authors is the application of the strength exercises, neuromuscular exercises, that is, the proprioceptive training which should also be more often included in practice handball coach education (Achenbach et al., 2018; Reckling et al., 2003). The return of a player to the training process and competition after knee injury depends on the individual ability of the player. The coach should also be a member of the rehabilitation team so that they could follow the injured player, optimize the load levels and make a decision as to the player's return to the regular training activities (Krstić \& Stamatović, 2018).

\section{CONCLUSION}

The aim of this work is to present and analyse the handball literature on the causes of injuries, types of injuries and their anatomic locations, as well as the prevention measurements. Based on the results of the analyzed studies, it can be concluded that there is a significant number of injuries, of different body parts and of different severity in top-level handball players. The frequency of more serious injuries to the lower extremities and the body among female players is higher in the games, whereas the injuries to the upper extremities, the head and the neck are more frequent during the training sessions. Overuse injuries (to certain body parts, such as the more dominant shoulder, the ankle and the knee) are considered to be most prominent. Majority of them occurs during the defensive activities (2/3) and the rest (1/3) during the counter-attacks of female players. Generally speaking, direct aggressive contacts between players, planting and running are the main causes of injuries in female handball players. In order to prevent the injuries to the mouth and teeth, the use of mouthguard is recommended particularly to those female players who are in the pivotal and goalkeeping positions since they are prone to such injuries. When it 
comes to the prevention and rehabilitation of shoulder injuries, the research results have shown positive effects that the training aiming at the increase of the inner rotation of the glenohumeral strength, the outer rotation strength and the scapular muscles strength has along with the exercises for improving the kinetic chain and the chest flexibility. The use of elastic bands and the medicine ball has proven efficient in increasing the shoulder area strength, and the whole swing and throw movement. The ankle and the knee are the most frequently injured joints among female handball players. The results of the application of the neuromuscular training, the proprioception and the balance exercises (on different balancers), combined with some specific players' activities (running, jumping and planting) show that such training process is efficient in the prevention of injuries to these parts of the lower extremities, so majority of authors recommend them as an obligatory part of the warming-up activity in the training sessions of handball players in the periods of preparations and competitions.

\section{REFERENCES}

Achenbach, L., Krutsch, V., Weber, J., Nerlich, M., Luig, P., Loose, O., et al. (2018). Neuromuscular exercises prevent severe knee injury in adolescent team handball players. Knee Surgery, Sports Traumatology, Arthroscopy: Official Journal of the ESSKA, 26 (7), 1901-1908. doi: 10.1007/s00167-017-4758-5.

Agel, J., Arendt, E.A., \& Bershadsky, B. (2005). Anterior cruciate ligament injury in national collegiate athletic association basketball and soccer: a 13-year review. American Journal of Sports Medicine, 33, 524-530. doi: 10.1177/ 0363546504269937.

Alentorn-Geli, E., Myer, G.D., Silvers, H.J., Samitier, G., Romero, D., Lázaro-Haro, C., et al. (2009). Prevention of non-contact anterior cruciate ligament injuries in soccer players. Part 2: a review of prevention programs aimed to modify risk factors and to reduce injury rates. Knee Surgery, Sports Traumatology, Arthroscopy, 17, 859-879. doi: 10.1007/s00167-009-0813-1.

Ameer, M.A., \& Muaidi, Q.I. (2017). Relation between peak knee flexion angle and knee ankle kinetics in single-leg jump landing from running: a pilot study on male handball players to prevent ACL injury. The Physician and Sportsmedicine, 45(3), 337-343. doi: 10.1080/00913847.2017.1344514.

Andersson, S.H., Bahr, R., Clarsen, B., \& Myklebust, G. (2016). Preventing overuse shoulder injuries among throwing athletes: a cluster-randomised controlled trial in 660 elite handball players. British Journal of Sports Medicine, 51(14), 1073-1080. doi: 10.1136/bjsports-2016-096226.

Andersson, S.H., Bahr, R., Clarsen, B., \& Myklebust, G. (2018). Risk factors for overuse shoulder injuries in a mixed-sex cohort of 329 elite handball players: previous findings could not be confirmed. British Journal of Sports Medicine, 52 (18), 1191-1198. doi: 10.1136/bjsports-2017-097648.

Arendt, E., \& Dick, R. (1995). Knee injury patterns among men and women in collegiate basketball and soccer. NCAA data and review of literature. AmericanJournal of Sports Medicine, 23, 694-701. doi: 10.1177/036354659502300611.

Bere, T., Alonso, J.M., Wangensteen, A., Bakken, A., Eirale, C., Dijkstra, H.P., et al. (2015). Injury and illness surveillance during the 24th Men's Handball World 
Championship 2015 in Qatar. British Journal of Sports Medicine, 49 (17), 1151-1156. doi: 10.1136/bjsports-2015-094972.

Bergman, L., Milardović Ortolan, S., Žarković, D., Viskić, J., Jokić, D., \& Mehulić, K. (2017). Prevalence of dental trauma and use of mouthguards in professional handball players. Dental Traumatology, 33 (3), 199-204. doi: 10.1111/edt.12323.

Bjordal, J.M., Arnly, F., Hannestad, B., \& Strandt, T. (1997). Epidemiology of anterior cruciate ligament injuries in soccer. American Journal of Sports Medicine, 25, 341-345. doi: 10.1177/036354659702500312.

Clarsen, B., Bahr, R., Andersson, S.H., Munk, R., \& Myklebust, G. (2014). Reduced glenohumeral rotation, external rotation weakness and scapular dyskinesis are risk factors for shoulder injuries among elite male handball players: a prospective cohort study. British Journal of Sports Medicine, 48, 1327-1333. doi: 10.1136/bjsports-2014-093702.

Clarsen, B., Myklebust, G., \& Bahr, R. (2012). Development and validation of a new method for the registration of overuse injuries in sports injury epidemiology. British Journal of Sports Medicine, 00, 1-8. doi:10.1136/bjsports-2012-091524.

Cools, A.M., Johansson, F.R., Borms, D., \& Maenhout, A. (2015). Prevention of shoulder injuries in overhead athletes: a science-based approach. Brazilian Journal of Physical Therapy, 19 (5), 331-339. doi: 10.1590/bjpt-rbf.2014.0109.

Eils, E., Schröter, R., Schröder, M., Gerss, J., \& Rosenbaum, D. (2010). Multistation proprioceptive exercise program prevents ankle injuries in basketball. Medicine \& Science in Sports \& Exercise, 42(11), 2098-2105. doi: 10.1249/MSS. 0b013e3181e03667.

Fagerli, U.M., Lereim, I., \& Sahlin, Y. (1990). Injuries in handball players. Tidsskrift for den Norske Lageforening: Tidsskrift for Praktisk Medicin, ny Rakke, 110, 475-478.

Fieseler, G., Jungermann, P., Koke, A., Irlenbusch, L., Delank, K.S., \& Schwesig, R. (2015). Range of motion and isometric strength of shoulder joints of team handball athletes during the playing season, Part II: changes after midseason. Journal of Shoulder and Elbow Surgery, 24, 391-398. doi: 10.1016/j.jse.2014. 07.019.

Giroto, N., Hespanhol Junior, L.C., Gomes, M.R.C., \& Lopes, A.D. (2017). Incidence and risk factors of injuries in Brazilian elite handball players: A prospective cohort study. Scandinavian Journal of Medicine \& Science in Sport, 27 (2), 195-202. doi: 10.1111/sms.12636.

Gohlke, F., Lippert, M.J., \& Keck, O. (1993). Instability and impingement of the shoulder of the high performance athlete in overhead stress. Sportverletz Sportschaden, 7, 115-121. doi: 10.1055/s-2007-993494.

Griffin, L.Y., Albohm, M.J., Arendt, E.A., Bahr, R., Beynnon, B.D., Demaio, M., et al. (2006). Understanding and preventing noncontact anterior cruciate ligament injuries: a review of the Hunt Valley II meeting. American Journal of Sports Medicine, 34, 1512-1532. doi: 10.1177/0363546506286866.

Herman, K., Barton, C., Malliaras, P., \& Morrissey, D. (2012). The effectiveness of neuromuscular warm-up strategies that require no additional equipment, for preventing lower limb injuries during sports participation: a systematic review. BMC Medicine, 10, 75-87. doi: 10.1186/1741-7015-10-75.

Hewett, T.E., Myer, G.D., \& Ford, K.R. (2006). Anterior cruciate ligament injuries in female athletes: Part 1, mechanisms and risk factors. American Journal of Sports Medicine, 34, 299-311. doi: 10.1177/0363546505284183.

Hootman, J.M., Dick, R., \& Agel, J. (2007). Epidemiology of collegiate injuries for 15 sports: Summary and recommendations for injury prevention initiatives. Journal of Athletic Training, 42, 311-319. 
Hrysomallis, C. (2007). Relationship between balance ability, training and sports injury risk. Sports Medicine, 37(6), 547-556. doi: 10.2165/00007256-200737060-00007.

Jost, B., Zumstein, M., Pfirrmann, C., Zanetti, M., \& Gerber, C. (2005). Findings in throwing shoulders: Abnormalities in professional handball players. Clinical Orthopaedics and Related Research, 434, 130-137. doi: 10.1097/01.blo. 0000154009.43568.8d.

Krosshaug, T., Nakamae, A., Boden, B.P., Engebretsen, L., Smith, G., Slauterbeck, J.R., et al. (2007). Mechanisms of anterior cruciate ligament injury in basketball: Video analysis of 39 cases. American Journal of Sports Medicine, 35, 359-367. doi: $10.1177 / 0363546506293899$.

Krstić, O., \& Stamatović, M. (2018). Physical treatment of sports knee injuries. Facta Universitatis Series Physical Education and Sport, 16(1), 211-220. doi: 10.22190/ fupes171204019k.

Langevoort, G., Myklebust, G., Dvorak, J., \& Junge, A. (2007). Handball injuries during major international tournaments. Scandinavian Journal of Medicine \& Science in Sport, 17 (4), 400-407. doi: 10.1111/j.1600-0838.2006.00587.x.

Laver L., \& Myklebust G. (2015). Handball injuries: Epidemiology and injury characterization. In: M. Doral \& J. Karlsson (Eds.) Sports injuries. Springer, Berlin, Heidelberg. https://doi.org/10.1007/978-3-642-36569-0_287

Laver, L., Landreau, P., Seil, R. \& Popović, N. (2018). Handball Sports Medicine Basic Science, Injury Management and Return to Sport. Berlin, Germany: Springer-Verlag GmbH, DE.

Lubiatowski, P., Kaczmarek, P., Cisowski, P., Breborowicz, E., Grygorowicz, M., Dzianach, M., et al. (2017). Rotational glenohumeral adaptations are associated with shoulder pathology in professional male handball players. Knee Surgery, Sports Traumatology, Arthroscopy, 26(1), 67-75. doi: 10.1007/s00167-0174426-9.

Mandelbaum, B.R., Silvers, H.J., Watanabe, D.S., Knarr, J.F., Thomas, S.D., Griffin, L.Y., et al. (2005). Effectiveness of a neuromuscular and proprioceptive training program in preventing anterior cruciate ligament injuries in female athletes: 2-year follow-up. American Journal of Sports Medicine, 33, 10031010. doi: 10.1177/0363546504272261.

Mascarin, N.C., de Lira, C.A.B., Vancini, R.L., de Castro Pochini, A., da Silva, A.C., \& dos Santos Andrade, M. (2017). Strength training using elastic bands: improvement of muscle power and throwing performance in young female handball players. Journal of Sport Rehabilitation, 26 (3), 245-252. doi: 10.1123/jsr.2015-0153.

McLean, S.G., Huang, X., Su, A., \& Van Den Bogert, A.J. (2004). Sagittal plane biomechanics cannot injure the ACL during sidestep cutting. Clinical Biomechanics (Bristol, Avon), 19, 828-838. doi: 10.1016/j.clinbiomech.2004. 06.006 .

McLean, S.G., Huang, X., \& Van Den Bogert, A.J. (2005a). Association between lower extremity posture at contact and peak knee valgus moment during sidestepping: Implications for ACL injury. Clinical Biomechanics, 20, 863870. doi: 10.1016/j.clinbiomech.2005.05.007.

McLean, S.G., Walker, K., Ford, K.R., Myer, G.D., Hewett, T.E., \& Van den Bogert, A.J. (2005b). Evaluation of a two dimensional analysis method as a screening and evaluation tool for anterior cruciate ligament injury. British Journal of Sports Medicine, 39, 355-362. doi: 10.1136/bjsm.2005.018598.

Meister, K., Buckley, B., \& Batts, J. (2004). The posterior impingement sign: diagnosis of rotator cuff and posterior labral tears secondary to internal impingement in overhand athletes. American Journal of Orthopedics, 33, 412-415. 
Michaelidis, M., \& Koumantakis, G.A. (2014). Effects of knee injury primary prevention programs on anterior cruciate ligament injury rates in female athletes in different sports: A systematic review. Physical Therapy in Sport, 15, 200-210. doi: 10.1016/j.ptsp.2013.12.002.

Myklebust, G., Engebretsen, L., Braekken, I.H., Skjølberg, A., Olsen, O.E., \& Bahr, R. (2003). Prevention of anterior cruciate ligament injuries in female team handball players: a prospective intervention study over three seasons. Clinical Journal of Sport Medicine, 13 (2), 71-78.

Myklebust, G., Hasslan, L., Bahr, R., \& Steffen, K. (2011). High Prevalence of shoulder pain among elite Norwegian female handball players. Scandinavian Journal of Medicine \& Science in Sport, 23, 288-294. doi: 10.1111/j.1600-0838.2011. 01398.x.

Nasiri, K. (1994). Cognition of causes and the rate of sport injuries in shoulder joint among elite handball players. Master Thesis, Tehran: Faculty of Physical Education and Sport Sciences, University of Tehran, Iran. doi: 10.1055/s-20071025037.

Nielsen, A.B., \& Yde, J. (1988) An epidemiologic and traumatologic study of injuries in handball. International Journal of Sports Medicine, 9, 341-344. doi: 10.1055/s2007-1025037.

Ødegaard, T.T., \& Risberg, M.A. (2005). Warm-up exercise prevents acute knee and ankle injuries in young handball players. Australian Journal of Physiotherapy, 51(2), 131.

Olsen, O.E., Myklebust, G., Engebretsen, L., \& Bahr, R. (2004). Injury mechanisms for anterior cruciate ligament injuries in team handball: a systematic video analysis. American Journal of Sports Medicine, 32, 1002-1012. doi: 10.1177/ 0363546503261724.

Olsen, O.E., Myklebust, G., Engebretsen, L., Holme, I., \& Bahr, R. (2005). Exercises to prevent lower limb injuries in youth sports: cluster randomised controlled trial. British Journal of Sports Medicine, 330, 449-456. doi: 10.1136/bmj.38330. $632801.8 \mathrm{~F}$.

Østerås, H., Sommervold, M., \& Skjølberg, A. (2014). Effects of a strength-training program for shoulder complaint prevention in female team handball athletes. A pilot study. The Journal of Sports Medicine and Physical Fitness, 55 (7-8), 761-767.

Paszkewicz, J., Webb, T., Waters, B., Welch McCarty, C., \& Van Lunen, B. (2012). The effectiveness of injury-prevention programs in reducing the incidence of anterior cruciate ligament sprains in adolescent athletes. Journal of Sport Rehabilitation, 21, 371-377. doi: 10.1177/2325967116634074.

Petersen, W., Zantop, T., Steensen, M., Hypa, A., Wessolowski, T., \& Hassenpflug, J. (2002). Prevention of lower extremity injuries in handball: Initial results of the handball injuries prevention programme. Sportverletz. Sportschaden, 16 (3), 122-126. doi: 10.1055/s-2002-34753.

Petersen, W., Braun, C., Bock, W., Schmidt, K., Weimann, A., Drescher, W., et al. (2005). A controlled prospective case control study of a prevention training program in female team handball players: the German experience. Archives of Orthopaedic and Trauma Surgery, 125 (9), 614. doi: 10.1007/s00402-005-0793-7.

Petrović, M., Kühl, S., Šlaj, M., Connert, T., \& Filippi, A. (2016). Dental and general trauma in team handball. Swiss Dental Journal, 126 (7-8), 682-686.

Popović, N., \& Lemaire, R. (2002). Hyperextension trauma to the elbow: radiological and ultrasonographic evaluation in handball goalkeepers. British Journal of Sports Medicine, 36, 452-456. doi: 10.1136/bjsm.36.6.452 
Raeder, C., Fernandez-Fernandez, J., \& Ferrauti, A. (2015). Effects of six weeks of medicine ball training on throwing velocity, throwing precision, and isokinetic strength of shoulder rotators in female handball players. The Journal of Strength \& Conditioning Research, 29(7), 1904-1914. doi: 10.1519/JSC.0000000000000847.

Rafnsson, E.T., Valdimarsson, Ö., Sveinsson, T., \& Árnason, Á. (2019). Injury pattern in icelandic elite male handball players. Clinical Journal of Sport Medicine, 29 (3), 232-237. doi: 10.1097/JSM.0000000000000499.

Rasuli, S., Jafari, A., Barghi Moghaddam, J., \& Narenjichi Shotorbani, F. (2012). The prevalence of sports injuries in female handball players. Advances in Environmental Biology, 6(5), 1801-1808.

Reckling, C., Zantop, T., \& Petersen, W. (2003). Epidemiology of injuries in juvenile handball players. Sportverletz, Sportschaden, 17(3), 112-117. doi: 10.1007/978-3642-36801-1287-1.

Renstrom, P., Ljungqvist, A., Arendt, E., Beynnon, B., Fukubayashi, T., Garrett, W., et al. (2008). Non-contact ACL injuries in female athletes: an International Olympic Committee current concepts statement. British Journal of Sports Medicine, 42, 394-412. doi: 10.1136/bjsm.2008.048934.

Seil, R., Rupp, S., Tempelhof, S., \& Kohn, D. (1997). Injuries during handball. A comparative, retrospective study between regional and upper league teams. Sportverletzung Sportschaden: Organ der Gesellschaft für OrthopädischTraumatologische Sportmedizin, 11(2), 58-62. doi: 10.1055/s-2007-993367.

Setuain, I., Millor, N., Alfaro, J., Gorostiaga, E., \& Izquierdo, M. (2015). Jumping performance differences among elite professional handball players with or without previous ACL reconstruction. Journal of Sports Medicine and Physical Fitness, 55(10), 1184-1192.

Shultz, S.J., Schmitz, R.J., Benjaminse, A., Chaudhari, A.M., Collins, M., \& Padua, D. (2012). ACL research retreat VI: an update on acl injury risk and prevention. Journal of Athletic Training, 47(5), 591-603. doi: 10.4085/1062-6050-47.5.13

Söderman, K., Werner, S., Pietilä, T., Engström, B., \& Alfredson H. (2000). Balance board training: prevention of traumatic injuries of the lower extremities in female soccer players? Knee Surgery, Sports Traumatology, Arthroscopy, 8(6), 356-363. doi: 10.1007/s001670000147.

Sommervold, M., \& Østerås, H. (2017). What is the effect of a shoulder-strengthening program to prevent shoulder pain among junior female team handball players? Open Access Journal of Sports Medicine, 8, 61-70. doi: 10.2147/OAJSM. S127854.

Steffen, K., Nilstad, A., Krosshaug, T., Pasanen, K., Killingmo, A., \& Bahr, R. (2017). No association between static and dynamic postural control and ACL injury risk among female elite handball and football players: a prospective study of 838 players. British Journal of Sports Medicine, 51, 253-259. doi: 10.1136/bjsports-2016-097068.

Svoboda, S.J., Owens, B.D., Harvey, T.M., Tarwater, P.M., Brechue, W.F., \& Cameron, K.L. (2016). The association between serum biomarkers of collagen turnover and subsequent anterior cruciate ligament rupture. American Journal of Sports Medicine, 44, 1687-1693. doi: 10.1177/0363546516640515.

Thacker, S.B., Stroup, D.F., Branche, C.M., Gilchrist, J., Goodman, R.A., \& Porter Kelling, E. (2003). Prevention of knee injuries in sports. A systematic review of the literature. Journal of Sports Medicine and Physical Fitness, 43(2), 165-179.

Vlak, T., \& Pivalica, D. (2004). Handball: the beauty or the beast. Croatian Medical Journal, 45(5), 526-530.

Waldén, M., Atroshi, I., Magnusson, H., Wagne, P., \& Hägglund, M. (2012). Prevention of acute knee injuries in adolescent female football players: Cluster randomised 
controlled trial. British Journal of Sports Medicine, 344, 3042-3053. doi: 10.1136/bmj.e3042.

Wedderkopp, N., Kaltoft, M., Holm, R., \& Froberg, K. (2003). Comparison of two intervention programmes in young female players in European handball - with and without ankle disc. Scandinavian Journal of Medicine \& Science in Sport, 13(6), 371-375.

Wedderkopp, N., Kaltoft, M., Lundgaard, B., Rosendahl, M., \& Froberg, K. (1999). Prevention of injuries in young female players in European team handball. A prospective intervention study. Scandinavian Journal of Medicine \& Science in Sport, 9, 41-47.

Zebis, M.K., Bencke, J., Andersen, L.L., Alkjaer, T., Suetta, C., Mortensen, P., et al. (2011). Acute fatigue impairs neuromuscular activity of anterior cruciate ligamentagonist muscles in female team handball players. Scandinavian Journal of Medicine \& Science in Sport, 21 (6), 833-840. doi: 10.1111/j.1600-0838.2010. 01052.x.

\title{
УЗРОЦИ И ПРЕВЕНЦИЈА ПОВРЕДА У РУКОМЕТУ
}

\author{
Ивана Бојић ${ }^{\mathbf{1}}$, Зоран Валдевит ${ }^{\mathbf{2}}$, Марина Величковић ${ }^{\mathbf{1}}$
}

${ }^{1}$ Универзитет у Нишу, Факултет спорта и физичког васпитања, Ниш, Србија

${ }^{2}$ Универзитет у Београду, Факултет спорта и физичког васпитања, Београд, Србија

\section{Резиме}

Периодичне допуне званичних правила рукометне игре указују на стални развој рукомета и његово унапређење, а који је очигледан кроз повећање брзине, снаге, техничких и тактичких способности играча. Најновије измене од јула 2016. године, поред осталих, посебан акценат дају строжим санкцијама за оштру и грубу контакт-игру између спортиста (увођење плавог картона након црвеног), све у циљу смањења броја повреда и повећања атрактивности и квалитета саме игре. Међутим, агресивни контакти су саставни део игре и неретко су узрок повређивања играча. Циљ овог рада наративно-прегледног карактера био је да се прегледом рукометне литературе анализирају узроци повреда, врсте повреда и њихова анатомска позиција, као и мере превенције повређивања играча. На основу резултата анализираних истраживања, постоји знатан број повреда, различите локације и степена тежине којима су изложени спортисти у врхунском рукомету. Учесталост тежих повреда рукометашица на доњим екстремитетима и трупу забележен је на утакмицама, док су током тренинга чешће повреде горњих екстремитета, главе и врата. Повреде узроковане прекомерном употребом појединих делова тела (доминантно раме, скочни зглоб и колено) сматрају се најбројнијим. Највећи број истих (око 2/3) настаје у одбрамбеним активностима, док $1 / 3$ повреда настаје у контранападима играчица. Уопштено гледано, директни агресивни контакти између играчица, доскоци и трчање спадају у главне узрочнике повређивања рукометашица. У циљу превенције повреде устију и зуба, препоручује се употреба гуменог штитника. У превенцији и рехабилитацији повреда рамена, резултати су показали позитивне ефекте вежби за повећање обима унутрашње и спољашње ротације и снаге мишића ротатора манжетне у зглобу рамена, као и вежби побољшања покретљивости грудног коша као дела отвореног и/или затвореног кинетичког ланца. Употреба еластичних трака и отежавајућих лопти „медицинки” показала се ефика- 
сним у повећању снаге раменог појаса, као и јачању целокупног покрета замаха избачаја лопте. Скочни зглоб и колено су међу најчешће повређиваним зглобовима рукометаша. Резултати примене неуромишићног тренинга, проприоцепције и вежби равнотеже, у комбинацији са специфичним активностима играча (трчање, скокови и приземљења) - показали су се ефикасним у превенцији повређивања скочног зглоба и колена, те их већина аутора препоручује као део загревања за тренинге у припремном и такмичарском периоду рукометаша. 